\title{
Physicochemical, Antioxidant and Sensorial Properties of Pasteurized Guava Nectar Incorporated with Pomegranate Peel and Guava Leaf Extracts
}

\author{
Sayed Mohamed Mokhtar, ${ }^{1, *}$, Ibrahim Mahmoud Ahmed Ibrahim² \\ ${ }^{1}$ Department of Food Technology, Faculty of Agriculture, Suez Canal University, Ismailia, Egypt \\ ${ }^{2}$ Department of Special Food and Nutrition, Food Technology Research Institute, Agriculture Research Center, Giza, Egypt \\ Email address: \\ smmokhtar@yahoo.com (S. M. Mokhtar),ibrahim256_mah@yahoo.com (I. M. A. Ibrahim) \\ ${ }^{*}$ Corresponding author
}

To cite this article:

Sayed Mohamed Mokhtar, Ibrahim Mahmoud Ahmed Ibrahim. Physicochemical, Antioxidant and Sensorial Properties of Pasteurized Guava Nectar Incorporated with Pomegranate Peel and Guava Leaf Extracts. World Journal of Food Science and Technology.

Vol. 4, No. 1, 2020, pp. 8-16. doi: 10.11648/j.wjfst.20200401.12

Received: March 5, 2020; Accepted: March 19, 2020; Published: April 14, 2020

\begin{abstract}
The aim of the present study was to evaluate the effect of pomegranate peel extract (PPE) and guava leaf extract (GLE) addition (0 "control", $0.1,0.2$ and $0.3 \%$ ) on physicochemical, antioxidant, microbiological and sensorial properties of pasteurized guava nectar during storage at room temperature $\left(25 \pm 5^{\circ} \mathrm{C}\right)$ for 6 months. PPE and GLE exhibited high total phenolic contents with 129.04 and $92.21 \mathrm{mg} / \mathrm{g}$, respectively and antioxidant activities with 91.15 and $87.34 \%$, respectively. The results showed that adding PPE and GLE increased total soluble solids, titratable acidity and browning index of nectar samples. However, $\mathrm{pH}$ and color $\left(L^{*}, a^{*}\right.$ and $\left.b^{*}\right)$ values were decreased. Furthermore, addition of PPE GLE significantly increased (compared to control) ascorbic acid (by 5.09 to $41.05 \%$ ), total phenolic content (by 62.24 to $164.93 \%$ ) and antioxidant activity (by 20.98 to $47.68 \%$ ). All nectar samples were microbiologically safe (total bacterial, yeast and mold counts were less than $10 \mathrm{CFU} / \mathrm{mL}$ ) and stable during storage. Sensory evaluation results revealed that the addition of PPE and GLE had no significant impact on all sensory properties. From the obtained results, it is concluded that the incorporation of guava nectar with PPE and GLE proved to be effective in the production of a safe nectar with better nutritional and sensorial qualities.
\end{abstract}

Keywords: Pomegranate Peel Extract, Guava Leaf Extract, Guava Nectar, Physicochemical Properties, Antioxidant Properties, Sensorial Properties

\section{Introduction}

Guava (Psidium guajava L.), a member of the Myrtaceae family, is a popular, exquisite and nutritious fruit crop of some tropical and subtropical regions of the world. It has a great appearance and pleasant flavor. In addition, guava is rich in vitamin $\mathrm{C}$, the guava content of vitamin $\mathrm{C}$ is equivalent to 2 to 5 times the citrus content, vitamin $\mathrm{A}$, niacin, riboflavin, thiamine, iron, calcium, potassium, magnesium, phosphorus and bioactive phytochemicals such as polyphenols. Guava is, however, highly perishable when stored at room temperature and must be preserved or processed into a number of products like pulp, paste, juice, jam, jelly, ice cream and canned slices in syrup [1-4].
Among the aforementioned products, guava juice is one of the most frequently consumed products in many regions around the world and has greater market potential. In recent years, the production of juices with nutraceutical properties like guava juice is the present need [2, 5-6]. World's cultivation area of the mangoes, mangosteens and guava fruits is approximately 6.286 million ha and 55.591 million tonnes of yield is obtained from this area. India, China, Thailand, Indonesia, Mexico and Pakistan are the main producer countries. Egypt ranks ninth among the world's top ten producers, with an annual production of about 1.351 million tonnes [7].

During processing and storage of fruit juices, various unfavorable quality changes occur such as loss of 
nutritional value, vitamin $\mathrm{C}$ degradation and polyphenolic content reduction, microbiological spoilage and undesirable color changes resulting from enzymatic and non-enzymatic browning [8-9]. Since quality is very important for fruit juices, chemical and microbiological deterioration should be controlled during processing and storage. Therefore, thermal processing such as pasteurization and chemical preservatives are used to inactivate microorganisms and enzymes for maintaining quality characteristics and prolonging the shelf life of fruit juices. Many chemical preservatives are commonly used in fruit and vegetables juices such as sodium benzoate, ascorbic and citric acids, potassium metabisulphite, potassium sorbate and their mixtures and, are generally recognized as safe [10-11]. However, excessive consumption of chemical preservatives has adverse effects on human health and they may cause severe toxicity such as genotoxicity and carcinogenicity [12]. In addition, consumer demand for safe foods without chemical preservatives leads to increase the interest in use natural preservatives such as plant extracts, essential oils, organic acids and bacteriocins.

Pomegranate (Punica granatum L.), a member of the Punicaceae family, is a popular, delicious and nutritious fruit consumed worldwide. The fruit is native to the Middle East and now extending throughout the Mediterranean region, India, China, South Africa and America and has traditionally been used in the folk medicine of India and many other countries [13-14]. The fruit is composed of three main parts: juice, seeds and peel. Pomegranate peel, which is produced as a by-product in huge quantities by the food industry representing about $40-50 \%$ of the fruit weight. Pomegranate peel is an important source of bioactive components, including gallic acid, ellagic acid and its derivatives, hexahydroxydiphenic acid and its derivatives, punicalin and punicalagin [15-16].

Guava leaves have been used as a traditional medicine in East Asia and some other countries for control and/or treatment of number of human diseases including hypertension, cough, diarrhea, liver, diabetes mellitus and obesity. Guava leaf extract contains many bioactive components such as polyphenolic compounds, and rosmarinic, gallic and caffeic acids, carvacrol, eugenol and catechin were the predominant phenolic compounds found in the extract [17-18]. These compounds have been demonstrated to exhibit several pharmacological effects like antioxidant, antimicrobial, anti-inflammatory, antipyretic and antispasmodic activities $[17,19]$. Therefore, pomegranate peel and guava leaf can be considered as valuable sources of bioactive components and recent studies reported the possibility of exploiting the pomegranate peel and guava leaf or their extracts as sources of natural antioxidant and antimicrobial agents [20-23]. The present study aimed at investigating the impact of pomegranate peel and guava leaf extracts on physicochemical, antioxidant, microbiological and sensorial properties of guava nectar stored at room temperature $\left(25 \pm 5^{\circ} \mathrm{C}\right)$ for 6 months.

\section{Materials and Methods}

\subsection{Materials and Chemicals}

Fresh fully matured guava (Psidium guajava L.) fruits of uniform size, free from fungal attack, bruises and mechanical damage and deep-green guava leaves were collected from the farm of Suez Canal University, Ismailia, Egypt. Fresh mature pomegranate (Punica granatum L.) fruits were collected from a local farm located in Ismailia, Egypt. FolinCiocalteu's phenol reagent, DPPH (2,2-diphenyl-1picrylhydrazyl), 2-Thiobarbituric acid and 2,6dichlorophenolindophenol were purchased from SigmaAldrich (St. Louis, MO, USA). All other chemicals and reagents were of the highest quality grade available and purchased from Fisher Scientific (Mumbai, India) and Qiyun Company (Guangzhou, China).

\subsection{Methods}

\subsubsection{Preparation of Pomegranate Peel and Guava Leaf Powders}

Pomegranate fruits were rinsed with tap water, manually peeled and then the peels were cutted using a sharp knife into small pieces $(\approx 1 \times 1 \mathrm{~cm})$. Guava leaves were rinsed with tap water and cutted into small pieces $(\approx 1 \times 2-3 \mathrm{~cm})$. The pieces of pomegranate peels and guava leaves were dried using a connective dryer (WT-binder, type F115, Germany) at $45^{\circ} \mathrm{C}$ for $24 \mathrm{~h}$. The dried pomegranate peel and guava leaf cuts were finely pulverized using an electric blender (Waring Commercial, HGB2WTS3, Torrington, Connecticut, USA), passed through a mesh $60(0.25 \mathrm{~mm})$ sieve shaker (Retsch, 5657 Haan, Germany) and then kept in sealed polyethylene bags at $4 \pm 1{ }^{\circ} \mathrm{C}$ for $24 \mathrm{~h}$ for extraction.

\subsubsection{Preparation of Pomegranate Peel and Guava Leaf Extracts}

The pomegranate peel and guava leaf powders (10 g) were extracted twice with an absolute ethanol $(100 \mathrm{~mL})$ by a constant agitation for $24 \mathrm{~h}$ at $100 \mathrm{rpm}$ using a laboratory shaker (Decoloring Table, TY-B, China). The ethanolic extracts of pomegranate peel and guava leaf powders were collected and filtered through Whatman (No. 4, $110 \mathrm{~mm}$ ) filter paper. The filtrates were evaporated to dryness using a rotary evaporation (Strike 300, Steroglass, Italy) under vacuum at $40^{\circ} \mathrm{C}$. Dried extracts of pomegranate peel [total phenolic content $(129.04 \pm 0.487 \mathrm{mg} / \mathrm{g})$ and antioxidant activity (91.15 $\pm 0.396 \%)$ ] and guava leaf [total phenolic content $(92.21 \pm 0.687 \mathrm{mg} / \mathrm{g})$ and antioxidant activity $(87.34 \pm 0.583 \%)]$ were kept at $-18^{\circ} \mathrm{C}$ until use.

\subsubsection{Preparation of Guava Nectar}

The fresh guava fruits were washed with running tap water to remove adhering dusts and to reduce the microbial load on the fruit surfaces, dried in air and cut into small slices prior to pulping using a Moulinex juice extractor (type 753, Moulinex, Spain). Guava pulp was passed through muslin cloth to remove seeds and coarse particles. For nectar production, the obtained guava pulp (10\%) was mixed with sucrose solution 
$(16 \%)$ at ratio of $1: 1(\mathrm{~V} / \mathrm{V})$. Then, citric acid, to adjust $\mathrm{pH}$ to 4.0 , and sodium benzoate $(0.1 \%)$ were added. The prepared nectar was divided into seven equal portions. The first portion did not include any natural extract as a control (CON; T1). Pomegranate peel extract (PPE) was added to the second, third and fourth portions at a concentration of 0.1 (T2), 0.2 (T3) and $0.3 \%$ (T4). Guava leaf extract (GLE) was added to the last three portions at a concentration of 0.1 (T5), 0.2 (T6) and $0.3 \%$ (T7). The treated nectar was filled into a sterilized glass bottle of $200 \mathrm{~mL}$ leaving a head space of 2 to $3 \mathrm{~cm}$ and sealed using a crown corking machine. After corking, the filled bottle was pasteurized at $98 \pm 2^{\circ} \mathrm{C}$ for $2 \mathrm{~min}$, suddenly cooled and then stored at room temperature. Physicochemical properties, microbiological stability and sensory properties of the prepared nectar were periodically evaluated up to 6 months of storage at an interval of two months i.e. $0,2,4$ and 6 months.

\subsubsection{Determination of Total Soluble Solids, $\mathrm{pH}$, Titratable Acidity and Ascorbic Acid}

The total soluble solids (TSS) values of the guava nectars were recorded at $20^{\circ} \mathrm{C}$ using an Abbe refractometer $(\mathrm{C} 10$, Vee Gee, USA) having range of 0-95 Brix. TSS values were expressed in Brix degrees. The $\mathrm{pH}$ values of the nectar samples were acquired at room temperature and a constant agitation with a Jenway $\mathrm{pH}$ meter (Jenway 3510, Bibby Scientific Ltd., Stone, Staffs, UK). The $\mathrm{pH}$ meter was calibrated at $\mathrm{pH} 4.0,7.0$ and 10.0 prior to use. Titratable acidity (TA) of nectar samples was estimated by titrating 10 $\mathrm{ml}$ of the guava nectar with $0.1 \mathrm{~N}$ sodium hydroxide $(\mathrm{NaOH})$ solution using $0.3 \mathrm{~mL}$ phenolphthalein as an indicator, light pink color persisting for 30 seconds is taken as an end point. The obtained TA values were expressed as \%, citric acid [24] Ascorbic acid content of the nectar samples was determined by a visual titration method using freshly prepared 2,6dichlorophenolindophenol dye solution. Ascorbic acid was expressed as $\mathrm{mg} / 100 \mathrm{~mL}$ nectar sample [24].

\subsubsection{Determination of Total Phenolic Content and Antioxidant Activity}

Total phenolic content (TPC) was estimated in the methanolic extract of PPE, GLE and nectar samples using the Folin-Ciocalteu colorimetric method of Osorio-Esquivel et al. [26]. Briefly, $1 \mathrm{~mL}$ of the extract was mixed with $5 \mathrm{~mL}$ of 10 -fold diluted Folin-Ciocalteu phenol reagent and $4 \mathrm{~mL}$ of $7.5 \% \mathrm{Na}_{2} \mathrm{CO}_{3}$, vortexed for $30 \mathrm{~s}$ and then the mixture was allowed to stand for $60 \mathrm{~min}$. The absorbance versus blank was read at $765 \mathrm{~nm}$ using a spectrophotometer (T80 UV/VIS, PG Instruments Ltd, UK). Six different concentrations of gallic acid solutions $(0-0.1 \mathrm{mg} / \mathrm{mL})$ were used for calibrations. The final results were expressed as milligrams of gallic acid equivalent (GAE) per $100 \mathrm{~mL}$ of the nectar sample. Antioxidant activity of the methanolic extract of PPE GLE and nectar samples was determined by DPPH $(2,2-$ diphenyl-1-picrylhydrazyl) assay according to the method of Ravichandran et al. [27]. Briefly, $0.1 \mathrm{~mL}$ of sample extract was mixed with $3.9 \mathrm{~mL}$ of DPPH solution for $30 \mathrm{~s}$ and then the mixture was incubated at room temperature for $30 \mathrm{~min}$. The absorbance was read spectrophotometrically at $515 \mathrm{~nm}$.

\subsubsection{Measurement of Instrumental Color and Color Index}

CIE $L^{*}, a^{*}$, and $b^{*}$ values of nectar samples were measured by the color reader CR-10 (Konika Minolta, Inc., Osaka, Japan). Color index, a measure of non-enzymatic browning, of nectar samples was determined according to the method of meydav et al. [25]. Nectar samples were centrifuged at $2000 \mathrm{rpm}$ for $20 \mathrm{~min}$, diluted with ethyl alcohol 95\% (1:1, v/v) and then filtered through Whatman (No. 4, $110 \mathrm{~mm}$ ) filter paper. The clarified extract was measured at $420 \mathrm{~nm}$ using a spectrophotometer.

\subsubsection{Microbiological Analysis}

The serial dilution and plating method were used to enumerate the microbial load of guava nectar samples. A 25 $\mathrm{mL}$ of nectar samples was homogenized in $225 \mathrm{~mL}$ of $0.1 \%$ peptone water. Appropriate dilutions were enumerated on nutrient agar and potato dextrose agar for total bacterial count (TBC) and yeast and mold count (YMC), respectively. The incubation of plates was done at $37^{\circ} \mathrm{C}$ for $48 \mathrm{~h}$ for $\mathrm{TBC}$ and at $25^{\circ} \mathrm{C}$ for 5 days for YMC. The mean results were expressed as log cell forming units (CFU) per millilitre.

\subsubsection{Sensory Evaluation}

The sensory evaluation of guava nectar samples was carried out according to the method of Min et al. [28]. A 9point hedonic scale $(9=$ like extremely and $0=$ dislike extremely) was used for evaluating the color, taste, aroma, mouth feel and overall acceptability of nectar samples. The mean score of thirty panelists for each sensory characteristic was calculated.

\subsubsection{Statistical Analysis}

Data were presented as mean values \pm standard deviation (SD) of three replications. Analysis of variance (ANOVA) for determining the significance between means of treatments at $(p<0.05)$ level was provided by SPSS software (version 17, SPSS Inc., Chicago, USA).

\section{Results and Discussion}

\subsection{Total Soluble Solids, $\mathrm{pH}$ and Titratable Acidity}

The effect of pomegranate peel extract (PPE) and guava leaf extract (GLE) addition on the total soluble solids (TSS), $\mathrm{pH}$ and titratable acidity (TA) during storage of guava nectar samples are shown in Figure 1a-c. Addition of PPE and GLE at different concentrations showed no significant $(p>0.05)$ effect on the TSS values of guava nectar samples. The initial TSS values in all nectar samples ranged from $14.07^{\circ}$ Brix for control (T1) and $14.20^{\circ}$ Brix for $0.3 \%$ PPE-containing nectar (T4). As clearly seen in Figure 1a, there was a gradual increase in the TSS values of all nectar samples with the advancement of storage. Increase in TSS values during storage might be attributed to a conversion of polysaccharides into simple sugars and oligosaccharides, a degradation of pectic substances in soluble solids and a solubilization of solids present in the nectars. Similar results were observed by Bal et al. [1] for guava nectar, Mall and 
Tondon [29] for guava anola blended beverage, Bhardwaj and Mukherjee [30] for kinnow juice and Rani et al. [31] for a mixture of mandarin and strawberry juice.

The $\mathrm{pH}$ values of PPE- and GLE-containing nectars were significantly $(p<0.05)$ lower than those of the control (Figure 1b). The $\mathrm{pH}$ showed a decreasing trend as the PPE and GLE addition level increased. The initial $\mathrm{pH}$ values in nectar samples ranged from 3.87 and 4.00. The highest initial $\mathrm{pH}$ value was found in the control (T1), while the lowest $\mathrm{pH}$ value was observed in $0.3 \%$ PPE-containing nectar (T4). Similar results for $\mathrm{pH}$ values with different addition levels of pomegranate peel powder have been reported by Saleh et al. [32]. This can be attributed to the acidic $\mathrm{pH}$ of pomegranate peel powder. During storage, the $\mathrm{pH}$ values significantly $(p<$ 0.05 ) decreased in all nectar samples.

Titratable acidity was significantly $(p<0.05)$ affected by

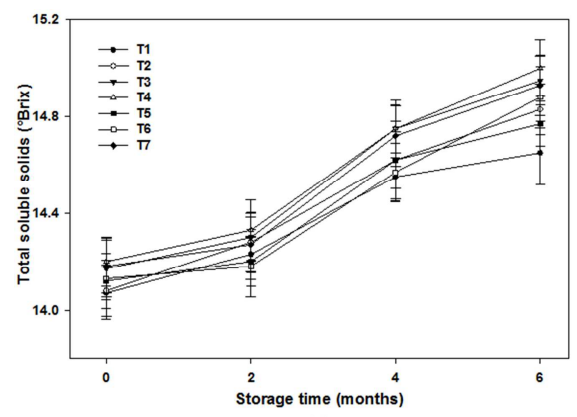

(a)

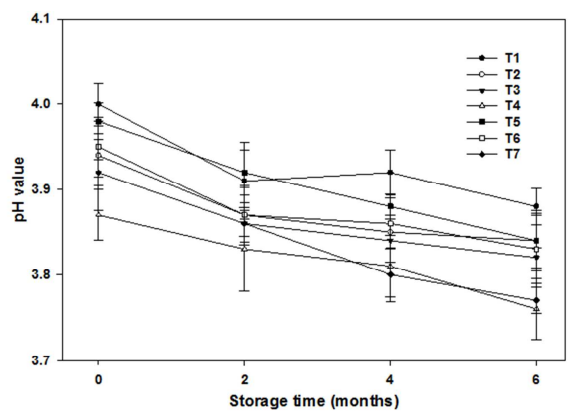

(b)

adding PPE and GLE. All PPE- and GLE-containing nectars showed significantly higher TA values (0.21-0.29\%) than the control $(0.20 \%)$. Titratable acidity of all guava nectar samples increased significantly during storage (Figure 1c). The increase in nectar acidity can be attributed to the formation of acids by hydrolysis of polysaccharides, oxidation of reducing sugars and the accelerated degradation of pectin substances [33-34]. The TA results of the present study are in accordance with the results of Bal et al. [1] for guava nectar, Mehmood et al. [34] for apple juice, Sharma et al. [6] for herbal apple-whey beverages and Rani et al. [31] for a mixture of mandarin and strawberry juice. On the other hand, de Sousa et al. [35] and Bhardwaj and Mukherjee [30] reported a decreasing trend in $\mathrm{TA} \%$ in tropical fruit mixed nectar and kinnow juice, respectively.

Figure 1. Effect of pomegranate peel extract (PPE) and guava leaf extract (GLE) on total soluble solids (a), pH (b) and Titratable acidity (c) of guava nectar during 6 months storage at room temperature. T1 (control), T2 (0.1\% PPE), T3 (0.2\% PPE), T4 (0.3\% PPE), T5 (0.1\% GLE), T6 (0.2\% GLE) and T7 (0.3\% $G L E)$. Results are presented as mean $\pm S D$ of triplicate determinations.

\subsection{Ascorbic Acid, Total Phenolic Content and Antioxidant Activity}

The effect of PPE and GLE addition on the ascorbic acid, total phenolic content (TPC) and antioxidant activity (AA) during storage of guava nectar samples are shown in Figure 2a-c. Significant differences $(p<0.05)$ of ascorbic acid contents were observed among the investigated nectar samples (Figure 2a). PPE- and GLE-containing nectars had higher contents of ascorbic acid $(58.67-78.75 \mathrm{mg} / 100 \mathrm{~mL})$ than the control $(55.83 \mathrm{mg} / 100 \mathrm{~mL})$. Also, the increase of ascorbic acid content was proportional with the PPE or GLE addition level. Significant $(p<0.05)$ decreases for ascorbic acid contents were observed during 6 months of storage in all nectar samples and the highest (calculated,\%) decline $(57.39 \%)$ occurred in the control (T1), while the lowest decline $(44.57 \%)$ occurred in $0.3 \%$ GLE-containing nectar (T7). This decrease might be due to the oxidation of ascorbic acid into dehydroascorbic acid in presence of oxygen [6]. Similar decreasing trend for ascorbic acid content was previously observed during storage of guava nectar [1], guava beverage [5], mandarin and strawberry mixed juice [31], apple juice [34] and carrot-goldenberry nectar [35]. Chia et al. [36] reported a significant decrease in ascorbic acid content of pineapple juice during 13 weeks of storage.

As, expected, the addition of PPE and GLE at different concentrations positively and significantly $(p<0.05)$ affected the TPC and antioxidant activity of nectar samples as shown in Figure 2b-c. The PPE-containing nectars (T2-T4) and GLE-containing nectars (T5-T7) had higher levels of TPC and antioxidant activity compared to the control. This effect can be attributed to the high levels of TPC (129.04 and 92.21 $\mathrm{mg} / \mathrm{g}$ ) and antioxidant activity (91.15 and $87.34 \%$ ) in PPE and GLE, respectively. Also, the levels of TPC and antioxidant activity of nectar samples was directly proportional to the levels of PPE and GLE, thus T4, T5 and T7 had the highest levels. Similar results were observed by Shalini and Ritu [22] Who reported that the increase guava leaf extract addition level in pineapple juice significantly increased its total phenolic content. Also, Chen and Yen [37] reported that guava leaf extract exhibited a concentrationdependent increase in its antioxidant activity. Similarly, Yasoubi et al. [38] mentioned that the antioxidant activity of pomegranate peel extract increased with the added addition level. During storage, a significant decrease of TPC and antioxidant activity were observed in all guava nectars. This decrease might be due to polyphenols condensation into brown pigments [39]. Present results are in agreement with the finding of Bal et al. [1] in guava nectar, Mehmood et al. [34] in apple juice, Muzaffar et al. [39] in pomegranate juice. At the end of storage, the lowest (calculated,\%) decrease in ascorbic acid, TPC and antioxidant activity values (44.57, 24.80 and $51.58 \%$, respectively) was recorded in the $0.3 \%$ 
GLE-containing nectar (T7), while the highest decrease (57.39, 38.44 and $62.90 \%$ respectively) was recorded in the control (T1). Conclusively, addition of PPE and GLE at all addition levels improved the nutritional quality of the nectar samples as evident from their higher ascorbic acid (58.67-

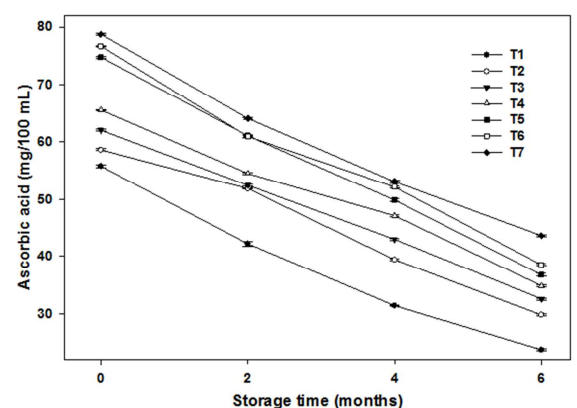

(a)

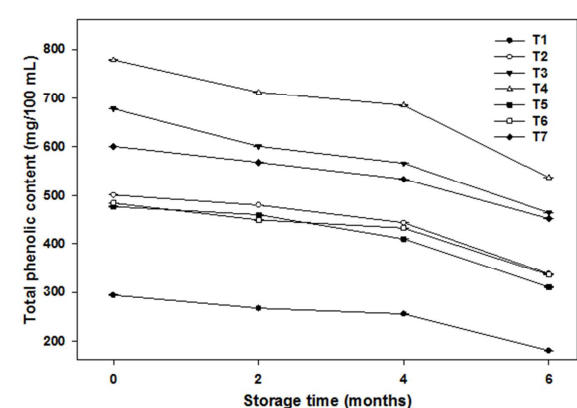

(b)
$78.75 \mathrm{mg} / 100 \mathrm{~mL})$, total phenolic contents (476.72-778.46 $\mathrm{mg} / 100 \mathrm{~mL})$ as well as antioxidant activity $(69.95-79.65 \%)$ compared to control $(55.83 \mathrm{mg} / 100 \mathrm{~mL}, 293.84 \mathrm{mg} / 100 \mathrm{~mL}$ and $57.82 \%$, respectively).

Figure 2. Effect of pomegranate peel extract (PPE) and guava leaf extract (GLE) on ascorbic acid (a), total phenolic content (b) and antioxidant activity (c) of guava nectar during 6 months storage at room temperature. T1 (control), T2 (0.1\% PPE), T3 (0.2\% PPE), T4 (0.3\% PPE), T5 (0.1\% GLE), T6 (0.2\% GLE) and $T 7(0.3 \%$ GLE). Results are presented as mean $\pm S D$ of triplicate determinations.

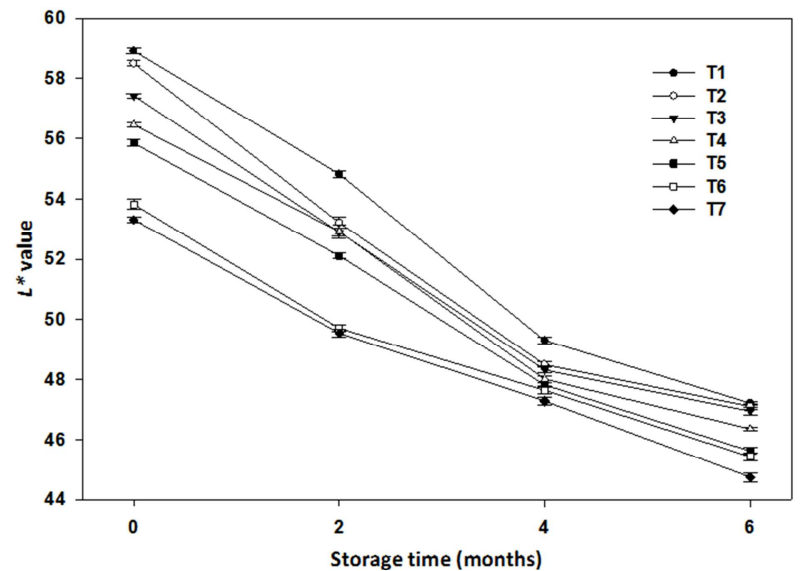

(a)

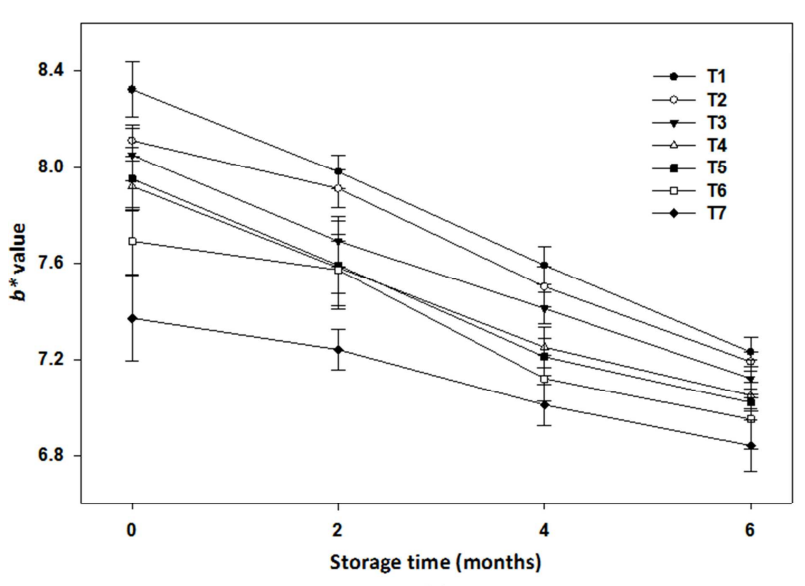

(c)

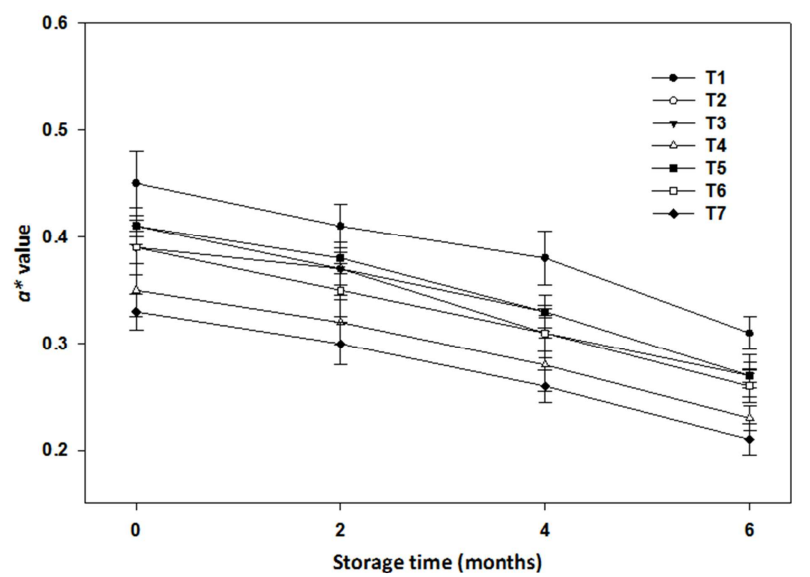

(b)

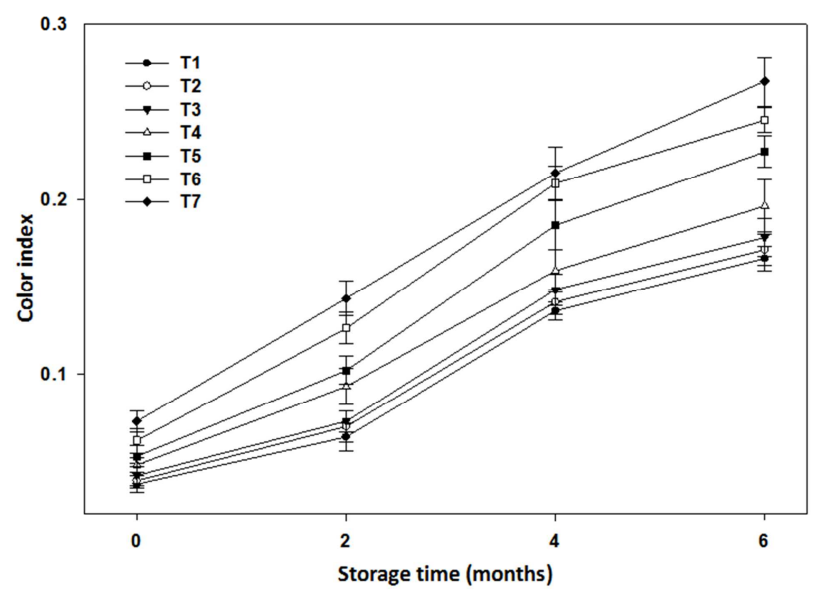

(d)

Figure 3. Effect of pomegranate peel extract (PPE) and guava leaf extract (GLE) on color parameters [L* (a), a* (b) and $\left.b^{*}(c)\right]$ and color index (d) of guava nectar during 6 months storage at room temperature. T1 (control), T2 (0.1\% PPE), T3 (0.2\% PPE), T4 (0.3\% PPE), T5 (0.1\% GLE), T6 (0.2\% GLE) and T7 $(0.3 \%$ GLE). Results are presented as mean $\pm S D$ of triplicate determinations.

\subsection{Instrumental Color and Color Index}

The effect of PPE and GLE addition on color $\left(L^{*}, a^{*}\right.$ and $\left.b^{*}\right)$ values and color index (CI) during storage of guava nectar samples are shown in Figure 3. The color $\left(L^{*}, a^{*}\right.$ and $\left.b^{*}\right)$ values in all nectar samples ranged from 53.31 to $58.92,0.33$ to 0.45 and 7.37 to 8.11 , respectively. Guava nectars with the addition of GLE and PPE had much lower $L^{*}, a^{*}$ and $b^{*}$ 
values than the control (Figure 3a-c). The greater GLE and PPE level of addition, the lower $L^{*}, a^{*}$ and $b^{*}$ values were recorded, and the $L^{*}, a^{*}$ and $b^{*}$ values of $0.3 \%$ GLEcontaining nectar (T7; 53.31, 0.33 and 7.37 , respectively) were lower than that of $0.3 \%$ PPE-containing nectar (T4; $56.45,0.35$ and 7.92 , respectively). This could be attributed to the dark color of both guava leaf and pomegranate peel extracts. Nevertheless, this differences in color values cannot be distinguished by the naked eye.

During storage, a significant decrease in color $\left(L^{*}, a^{*}\right.$ and $\left.b^{*}\right)$ values of all nectar samples were observed (Figure $\left.3 a-c\right)$. This decrease might be attributed to oxidation of heatsensitive pigments and non-enzymatic browning such as ascorbic acid oxidation. Similar results were reported by Embaby and Mokhtar [35] for carrot-goldenberry nectar and Chia et al. [36] for pineapple juice. Also, a significant decrease was found in $L^{*}, a^{*}$ and $b^{*}$ values of red guava juice during 180 storage days [11]. In contrast, Oziyci et al. [40] reported an increase in $L^{*}, a^{*}$ and $b^{*}$ values of pomegranate juice during storage at $15^{\circ} \mathrm{C}$.

Absorption at $420 \mathrm{~nm}$ of the alcohol extracts of guava nectars was used as an indicator of non-enzymatic browning. Significant differences $(p<0.05)$ were observed among the investigated nectars (Figure 3d). Guava nectars with the addition of PPE and GLE had much higher CI values than the control. The lowest initial CI value was determined in the control with 0.037 . However, the highest CI value was determined in $0.3 \%$ GLE-containing nectar (T7) with 0.073 . The CI increased significantly $(p<0.05)$ in all guava nectars by progress of storage time. The lowest (calculated, \%) rate $(265.75 \%)$ of increase in the CI was observed in GLEcontaining nectar (T7). However, the highest rate (348.65\%) of increase in the CI was observed in the control. This change could be mainly due to the non-enzymatic browning or oxidation of phenols which leads to the formation of brown pigments [30]. Similar results were reported by Bhardwaj and Mukherjee [30] for kinnow juice and Adeogun et al. [41] for sweet orange juice. Also, Vegara et al. [42] reported a rapid increase in browning index of pomegranate juice during storage at $25^{\circ} \mathrm{C}$.

\subsection{Microbiological Analysis}

The microbiological analysis (total bacterial, yeast and mold counts) of the investigated nectar samples, immediately after processing and during storage, showed that the counts of total bacterial, yeast and mold were less than $10 \mathrm{CFU} / \mathrm{mL}$ (data not shown). The obtained results were in compliance with the requirements of Egyptian nectar standards, EOS No. 1602-1/2005. Thus, the guava nectars were considered as safe for consumption due to their low microbial load. This might be due to the inhibitory effect of the added PPE and GLE, as well as the thermal pasteurization $\left(98 \pm 2^{\circ} \mathrm{C} / 2 \mathrm{~min}\right)$ and the low $\mathrm{pH}$ (3.87-4.00) values of the examined nectar samples. Similar results during 6 months of storage at ambient temperature were observed by Silva et al. [11] for red guava juice, de Sousa et al. [35] for tropical fruit mixed nectar and Akubor [43] for pineapple squash. Furthermore, non-detectable counts of bacteria, yeast and mold in the redfleshed dragon fruit juice during 6 weeks of storage at 4 and $25^{\circ} \mathrm{C}$ were reported by Siow and Wong [44].

\subsection{Sensory Evaluation}

The effect of PPE and GLE addition on the sensory properties during storage of guava nectar samples are presented in Table 1. The results showed that all nectar samples had high color, taste, odor, appearance, mouthfeel and overall acceptability scores at the beginning of storage. There were no significant differences $(p>0.05)$ in the ratings for color, mouthfeel and overall acceptability of the nectar samples during the six months storage, but with regard to taste, odor and appearance significant differences $(p<0.05)$ were observed among the PPE- and GLE-containing nectars and the control at the fourth and sixth months of storage. Although, nectars formulated with PPE and GLE had the highest scores compared to control for the examined sensory characteristics during storage. The obtained results are in accordance with those of Silva et al. [11] in red guava juice and Barros et al. [20] for guava juice. Islam et at. [21] and Tabassum et al. [23] reported that adding guava leaf extract maintained color, flavor and firmness of banana in comparison with control during storage. On the other hand, Shalini and Ritu [22] found significant differences between the control and GLE-containing beverages with regard to color, flavor, taste, consistency and overall acceptability.

The scores of all sensory properties were decreased over the 6 months storage, but the PPE-containing nectars (T2-T4) and GLE-containing nectars (T5-T7) were significantly more satisfying compared to the control samples in all sensory properties. The reduction in the scores of sensory characteristic might be attributed to the non-enzymatic browning reactions which have led to the formation of brown pigments, the possible loss of volatile compounds, the breakdown of polysaccharides and the degradation of colloidal particles and protein as well as the formation of complexes with pectin and phenolics during storage at room temperature $[1,6]$. Similar decreasing trend in sensory characteristics scores during storage has been reported by Bal et al. [1] for guava nectar, Moazzem et al. [9] for apple beverages and Rani et al. [31] for a mixture of mandarin and strawberry juice. By the end of storage time, the $0.1 \%$ and $0.2 \%$ PPE-containing nectars (T2 and T3) exhibited the highest scores of color with 7.80 and 7.80 , taste with 7.70 and 7.67, odor with 7.89 and 7.80, appearance with 8.00 and 7.90, mouthfeel with 7.56 and 7.60, and overall acceptability with 7.80 and 7.70, respectively. However, the control (T1) showed the lowest sensorial scores with 7.10, 6.90, 6.90, 6.89, 7.50 and 7.00, respectively. Moreover, a higher retention of all sensory characteristics was observed in PPE- and GLEcontaining nectars in comparison with control. This may be explained as PPE and GLE inhibit microbial growth and enzymatic activity in stored nectars, which deteriorate the natural color and taste, and produce off flavor. Despite the score's reduction, the investigated sensory properties of all nectar samples maintained the acceptance region of the 9- 
point hedonic scale.

Table 1. Effect of pomegranate peel extract (PPE) and guava leaf extract (GLE) on sensory properties of guava nectar during 6 months storage at room temperature.

\begin{tabular}{|c|c|c|c|c|c|}
\hline \multirow{2}{*}{ Parameter } & \multirow{2}{*}{ Treatment } & \multicolumn{4}{|c|}{ Storage time (months) } \\
\hline & & $\mathbf{0}$ & 2 & 4 & 6 \\
\hline \multirow[t]{7}{*}{ Color } & $\mathrm{CON}$ & $8.60 \pm 0.516 \mathrm{Aa}$ & $8.10 \pm 0.738 \mathrm{Aab}$ & $7.90 \pm 0.876 \mathrm{Ab}$ & $7.10 \pm 0.568 \mathrm{Ac}$ \\
\hline & PPE1 & $8.80 \pm 0.422 \mathrm{Aa}$ & $8.67 \pm 0.500 \mathrm{Aa}$ & $8.30 \pm 0.675 \mathrm{Aab}$ & $7.80 \pm 0.789 \mathrm{Ab}$ \\
\hline & PPE2 & $8.50 \pm 0.527 \mathrm{Aa}$ & $8.56 \pm 0.527 \mathrm{Aa}$ & $8.20 \pm 0.632 \mathrm{Aab}$ & $7.80 \pm 0.789 \mathrm{Ab}$ \\
\hline & PPE3 & $8.40 \pm 0.516 \mathrm{Aa}$ & $8.44 \pm 0527 \mathrm{Aa}$ & $8.20 \pm 0.789 \mathrm{Aab}$ & $7.70 \pm 0.823 \mathrm{Aa}$ \\
\hline & GLE1 & $8.60 \pm 0.516 \mathrm{Aa}$ & $8.50 \pm 0.527 \mathrm{Aa}$ & $8.20 \pm 0.789 \mathrm{Aab}$ & $7.70 \pm 0.823 \mathrm{Ab}$ \\
\hline & GLE2 & $8.40 \pm 0.516 \mathrm{Aa}$ & $8.44 \pm 0.527 \mathrm{Aa}$ & $8.10 \pm 0.876 \mathrm{Aa}$ & $7.80 \pm 0.632 \mathrm{Aa}$ \\
\hline & GLE3 & $8.40 \pm 0.516 \mathrm{Aa}$ & $8.25 \pm 0.463 \mathrm{Aa}$ & $8.00 \pm 0.816 \mathrm{Aab}$ & $7.60 \pm 0.699 \mathrm{Ab}$ \\
\hline \multirow[t]{7}{*}{ Taste } & $\mathrm{CON}$ & $8.60 \pm 0.516 \mathrm{Aa}$ & $7.90 \pm 0.738 \mathrm{Ab}$ & $7.40 \pm 0.516 \mathrm{Bc}$ & $6.90 \pm 0.316 \mathrm{Bd}$ \\
\hline & PPE1 & $8.89 \pm 0.333 \mathrm{Aa}$ & $8.56 \pm 0.527 \mathrm{Aab}$ & $8.20 \pm 0.789 \mathrm{Abc}$ & $7.70 \pm 0.675 \mathrm{Ac}$ \\
\hline & PPE2 & $8.78 \pm 0.441 \mathrm{Aa}$ & $8.40 \pm 0.843 \mathrm{Aa}$ & $8.30 \pm 0.823 \mathrm{Aab}$ & $7.67 \pm 0.707 \mathrm{Ab}$ \\
\hline & PPE3 & $8.80 \pm 0.422 \mathrm{Aa}$ & $8.40 \pm 0.516 \mathrm{Aa}$ & $8.22 \pm 0.823 \mathrm{Aab}$ & $7.60 \pm 0.843 \mathrm{ABb}$ \\
\hline & GLE1 & $8.67 \pm 0.500 \mathrm{Aa}$ & $8.50 \pm 0.527 \mathrm{Aa}$ & $8.20 \pm 0.632 \mathrm{Aa}$ & $7.60 \pm 0.843 \mathrm{ABb}$ \\
\hline & GLE2 & $8.70 \pm 0.483 \mathrm{Aa}$ & $8.40 \pm 0.699 \mathrm{Aa}$ & $8.10 \pm 0.738 \mathrm{ABab}$ & $7.56 \pm 0.882 \mathrm{ABb}$ \\
\hline & GLE3 & $8.60 \pm 0.516 \mathrm{Aa}$ & $8.20 \pm 0.789 \mathrm{Aa}$ & $8.10 \pm 0.876 \mathrm{ABa}$ & $7.44 \pm 0.527 \mathrm{ABb}$ \\
\hline \multirow[t]{7}{*}{ Odor } & $\mathrm{CON}$ & $8.70 \pm 0.483 \mathrm{Aa}$ & $8.20 \pm 0.919 \mathrm{Aab}$ & $7.60 \pm 0.843 \mathrm{Ab}$ & $6.90 \pm 0.316 \mathrm{Bc}$ \\
\hline & PPE1 & $8.75 \pm 0.463 \mathrm{Aa}$ & $8.50 \pm 0.707 \mathrm{Aab}$ & $8.11 \pm 0.601 \mathrm{Ab}$ & $7.89 \pm 0.601 \mathrm{Ab}$ \\
\hline & PPE2 & $8.70 \pm 0.483 \mathrm{Aa}$ & $8.40 \pm 0.699 \mathrm{Aab}$ & $8.00 \pm 0.707 \mathrm{Abc}$ & $7.80 \pm 0.919 \mathrm{Ab}$ \\
\hline & PPE3 & $8.70 \pm 0.675 \mathrm{Aa}$ & $8.44 \pm 0.726 \mathrm{Aab}$ & $8.00 \pm 0.816 \mathrm{Abc}$ & $7.70 \pm 0.483 \mathrm{Ac}$ \\
\hline & GLE1 & $8.78 \pm 0.441 \mathrm{Aa}$ & $8.56 \pm 0.527 \mathrm{Aa}$ & $8.10 \pm 0.738 \mathrm{Aab}$ & $7.60 \pm 0.843 \mathrm{Ac}$ \\
\hline & GLE2 & $8.67 \pm 0.500 \mathrm{Aa}$ & $8.30 \pm 0.675 \mathrm{Aab}$ & $7.90 \pm 0.876 \mathrm{Ab}$ & $7.70 \pm 0.675 \mathrm{Ab}$ \\
\hline & GLE3 & $8.63 \pm 0.518 \mathrm{Aa}$ & $8.33 \pm 0.500 \mathrm{Aab}$ & $7.89 \pm 0.782 \mathrm{Abc}$ & $7.60 \pm 0.510 \mathrm{Ac}$ \\
\hline \multirow[t]{7}{*}{ Appearance } & $\mathrm{CON}$ & $8.56 \pm 0.527 \mathrm{Aa}$ & $7.90 \pm 0.632 \mathrm{Ab}$ & $7.50 \pm 0.850 \mathrm{Ab}$ & $6.89 \pm 0.333 \mathrm{Bc}$ \\
\hline & PPE1 & $8.80 \pm 0.422 \mathrm{Aa}$ & $8.50 \pm 0.527 \mathrm{Aab}$ & $8.25 \pm 0.886 \mathrm{Aab}$ & $8.00 \pm 0.471 \mathrm{Ab}$ \\
\hline & PPE2 & $8.67 \pm 0.500 \mathrm{Aa}$ & $8.50 \pm 0.707 \mathrm{Aab}$ & $8.20 \pm 0.789 \mathrm{Aab}$ & $7.90 \pm 0.738 \mathrm{Ab}$ \\
\hline & PPE3 & $8.67 \pm 0.707 \mathrm{Aa}$ & $8.44 \pm 0.527 \mathrm{Aab}$ & $8.25 \pm 0.707 \mathrm{Aab}$ & $7.90 \pm 0.876 \mathrm{Ab}$ \\
\hline & GLE1 & $8.78 \pm 0.441 \mathrm{Aa}$ & $8.50 \pm 0.850 \mathrm{Aab}$ & $8.22 \pm 0.833 \mathrm{Aab}$ & $7.89 \pm 0.928 \mathrm{Ab}$ \\
\hline & GLE2 & $8.60 \pm 0.516 \mathrm{Aa}$ & $8.40 \pm 0.516 \mathrm{Aab}$ & $8.10 \pm 0.994 \mathrm{Aab}$ & $7.80 \pm 0.789 \mathrm{Ab}$ \\
\hline & GLE3 & $8.70 \pm 0.483 \mathrm{Aa}$ & $8.30 \pm 0.823 \mathrm{Aab}$ & $8.11 \pm 0.782 \mathrm{Aab}$ & $7.75 \pm 0.886 \mathrm{Ab}$ \\
\hline \multirow[t]{7}{*}{ Mouthfeel } & $\mathrm{CON}$ & $8.50 \pm 0.527 \mathrm{Aa}$ & $8.20 \pm 0.789 \mathrm{Aab}$ & $7.80 \pm 0.789 \mathrm{Aab}$ & $7.50 \pm 0.850 \mathrm{Ab}$ \\
\hline & PPE1 & $8.40 \pm 0.516 \mathrm{Aa}$ & $8.20 \pm 0.632 \mathrm{Aab}$ & $7.78 \pm 0.833 \mathrm{Aab}$ & $7.56 \pm 0.726 \mathrm{Ab}$ \\
\hline & PPE2 & $8.50 \pm 0.707 \mathrm{Aa}$ & $8.22 \pm 0.667 \mathrm{Aab}$ & $7.90 \pm 0.738 \mathrm{Aab}$ & $7.60 \pm 0.699 \mathrm{Ab}$ \\
\hline & PPE3 & $8.67 \pm 0.707 \mathrm{Aa}$ & $8.30 \pm 0.823 \mathrm{Aab}$ & $7.90 \pm 0.876 \mathrm{Abc}$ & $7.50 \pm 0.707 \mathrm{Ac}$ \\
\hline & GLE1 & $8.50 \pm 0.527 \mathrm{Aa}$ & $8.11 \pm 0.782 \mathrm{Aab}$ & $7.80 \pm 0.919 \mathrm{Ab}$ & $7.44 \pm 0.527 \mathrm{Ab}$ \\
\hline & GLE2 & $8.60 \pm 0.516 \mathrm{Aa}$ & $8.20 \pm 0.422 \mathrm{Aab}$ & $7.70 \pm 0.823 \mathrm{Abc}$ & $7.44 \pm 0.726 \mathrm{Ac}$ \\
\hline & GLE3 & $8.60 \pm 0.699 \mathrm{Aa}$ & $8.30 \pm 0.675 \mathrm{Aab}$ & $7.80 \pm 0.919 \mathrm{Abc}$ & $7.50 \pm 0.527 \mathrm{Ac}$ \\
\hline \multirow[t]{7}{*}{ Overall acceptability } & $\mathrm{CON}$ & $8.60 \pm 0.516 \mathrm{Aa}$ & $8.00 \pm 0.943 \mathrm{Aab}$ & $7.60 \pm 0.516 \mathrm{Abc}$ & $7.00 \pm 0.816 \mathrm{Ac}$ \\
\hline & PPE1 & $8.67 \pm 0.500 \mathrm{Aa}$ & $8.50 \pm 0.527 \mathrm{Aa}$ & $8.30 \pm 0.483 \mathrm{Aab}$ & $7.80 \pm 0919 \mathrm{Ab}$ \\
\hline & PPE2 & $8.56 \pm 0.726$ Aa & $8.44 \pm 0.882 \mathrm{Aab}$ & $8.22 \pm 0.833 \mathrm{Aab}$ & $7.70 \pm 0.675 \mathrm{Ab}$ \\
\hline & PPE3 & $8.70 \pm 0.483 \mathrm{Aa}$ & $8.40 \pm 0.699 \mathrm{Aa}$ & $8.20 \pm 0.789 \mathrm{Aa}$ & $7.56 \pm 0.527 \mathrm{Ab}$ \\
\hline & GLE1 & $8.56 \pm 0.527 \mathrm{Aa}$ & $8.33 \pm 0.866 \mathrm{Aab}$ & $8.20 \pm 0.919 \mathrm{Aab}$ & $7.60 \pm 0.966 \mathrm{Ab}$ \\
\hline & GLE2 & $8.60 \pm 0.516 \mathrm{Aa}$ & $8.30 \pm 0.675 \mathrm{Aa}$ & $8.33 \pm 0.707 \mathrm{Aa}$ & $7.60 \pm 0.843 \mathrm{Ab}$ \\
\hline & GLE3 & $8.50 \pm 0.707 \mathrm{Aa}$ & $8.30 \pm 0.949 \mathrm{Aa}$ & $8.20 \pm 0.789 \mathrm{Aab}$ & $7.50 \pm 0.756 \mathrm{Ab}$ \\
\hline
\end{tabular}

Mean values in the same column bearig different capital letters $(\mathrm{A}, \mathrm{B}, \mathrm{C})$ are significantly different $(\mathrm{p}<0.05)$ between nectar treatments at the same storage month. Mean values in the same raw bearig different small letters $(a, b, c)$ are significantly different $(p<0.05)$ between storage months at the same treatment. T1 (control), T2 $(0.1 \%$ PPE), T3 $(0.2 \%$ PPE), T4 $(0.3 \%$ PPE), T5 $(0.1 \%$ GLE), T6 $(0.2 \%$ GLE) and T7 (0.3\% GLE). Results are presented as mean \pm SD of triplicate determinations.

\section{Conclusion}

In the present study, physicochemical, antioxidant and sensorial properties as well as microbiological stability of pasteurized guava nectar incorporated with PPE and GLE (0, $0.1,0.2$ and $0.3 \%$ ) were evaluated. PPE- and GLE-containing nectars had the lowest $\mathrm{pH}$ and color $\left(L^{*}, a^{*}\right.$ and $\left.b^{*}\right)$ values, and showed the lowest decline rate in all color parameters during storage compared to control. Addition of PPE and
GLE significantly and positively increased total phenolic content and antioxidant activity of nectars. Also, all evaluated nectars were safe and stable during storage. During storage, PPE and GLE-containing nectars had higher sensory scores of color, taste, odor and appearance, mouthfeel and overall acceptability compared to the control. From the obtained results it could be concluded that PPE and GLE (as a natural sources of antioxidants) at the examined addition levels can be used to improve nectar characteristics and retard quality deterioration of guava nectar during storage. 
$397-405$.

\section{References}

[1] Bal, L. M., T. Ahmad, A. K. Senapati, and P. S. Pandit (2014) Evaluation of quality attributes during storage of guava nectar cv. Lalit from different pulp and TSS ratio. Journal of Food Processing and Technology 5, 1000329.

[2] de Sousa, P. H. M., G. A. Maia, H. M. C. de Azeredo, A. M. Ramos, and R. W. Figueiredo (2016) Storage stability of a tropical fruit (cashew apple, acerola, papaya, guava and passion fruit) mixed nectar added caffeine. International Journal of Food Science and Technology 45, 2162-2166.

[3] K. S. Gill, "Guavas," in: Encyclopedia of Food and Health, B. Caballero, P. M. Finglas and F. Toldrá, Eds. New York: Academic Press, 2016, pp. 270-277.

[4] Lamo, C., N. C. Shahi, A. Singh, and A. K. Singh (2019) Pasteurization of guava juice using induction pasteurizer and optimization of process parameters. LWT- Food Science and Technology 112, 108253.

[5] Kumar S. N. S., K. N. Sreenivas, T. H. Shankarappa, and V. Ravindra (2012) Standardization of recipe for value added nutraceutical beverages of guava blended with Aloe vera and roselle. Environment and Ecology 30, 995-1001.

[6] Sharma, R., R. Choudhary, N. S. Thakur, and A. Thakur (2019) Development and quality of apple-whey based herbal functional ready-to-serve beverage. Journal of Applied and Natural Science 11, 291-298.

[7] FAOSTAT (2017) Agricultural data, agricultural production, crop primary. http://www.fao.org/faostat/en/\#data/QC.

[8] Terefe, N. S., R. Buckow, and C. Versteeg (2014) Qualityrelated enzymes in fruit and vegetable products: Effects of novel food processing technologies, Part 1: High-pressure processing. Critical Reviews in Food Science and Nutrition 54, 24-63.

[9] Moazzem, M. S., M. B. H. Sikder, and W. Zzaman (2019) Shelf-life extension of wood apple beverages maintaining consumption-safe parameters and sensory qualities. Beverages 5,25 .

[10] Aneja, K. R., R. Dhiman, N. K. Aggarwal, and A. Aneja (2014) Emerging preservation techniques for controlling spoilage and pathogenic microorganisms in fruit juices. International Journal of Microbiology 2014, 758942.

[11] Silva, N. K. V., L. B. D. Sabino, L. S. de Oliveira, L. B. D. Torres, and P. H. M. de Sousa (2016) Effect of food additives on the antioxidant properties and microbiological quality of red guava juice. Revista Ciência Agronômica 47, 77-85.

[12] Williams, G. M., M. J. Iatropoulos, and J. Whysner (1999) Safety assessment of butylated hydroxyanisole and butylated hydroxytoluene as antioxidant food additives. Food and Chemical Toxicology 37, 1027-1038.

[13] Endo, E. H., D. A. Garcia Cortez, T. Ueda-Nakamura, C. V. Nakamura, and B. P. Dias Filho (2010) Potent antifungal activity of extracts and pure compound isolated from pomegranate peels and synergism with fluconazole against Candida albicans. Research in Microbiology 161, 534-540.

[14] Ismail, T., P. Sestili, and S. Akhtar (2012) Pomegranate peel and fruit extracts: A review of potential anti-inflammatory and anti-infective effects. Journal of Ethnopharmacology 143,

[15] Hasnaoui, N., B. Wathelet, and A. Jiménez-Araujo (2014) Valorization of pomegranate peel from 12 cultivars: Dietary fibre composition, antioxidant capacity and functional properties. Food Chemistry 160, 196-203.

[16] Gullon, B., M. E. Pintado, J. A. Pérez-Álvarez, and M. ViudaMartos (2016) Assessment of polyphenolic profile and antibacterial activity of pomegranate peel (Punica granatum) flour obtained from co-product of juice extraction. Food Control 59, 94-98.

[17] Jang, M., S. W. Jeong, S. K. Cho, H. J. Yang, D. S. Yoon, J. C. Kim, and K. H. Park (2014) Improvement in the antiinflammatory activity of guava (Psidium guajava L.) leaf extracts through optimization of extraction conditions. Journal of Functional Foods 10, 61-168.

[18] Ademiluyi, A. O., G. Oboh, O. B. Ogunsuyi, and F. M. Oloruntoba (2016) A comparative study on antihypertensive and antioxidant properties of phenolic extracts from fruit and leaf of some guava (Psidium guajava L.) varieties. Comparative Clinical Pathology 25, 363-374.

[19] Lozoya, X., H. Reyes-Morales, M. A. Chavez-Soto, M. D. C. Martinez-Garcia, Y. Soto-Gonzalez, and S. V. Doubova (2002) Intestinal anti-spasmodic effect of a phytodrug of Psidium guajava folia in the treatment of acute diarrheic disease. Journal of Ethnopharmacology 83, 19-24.

[20] Barros, Z. M. P., J. M. Salgado, P. S. Melo, and F. O. Biazotto (2014) Enrichment of commercially-prepared juice with pomegranate (Punica granatum L.) peel extract as a source of antioxidants. Journal of Food Research 3, 197-187.

[21] Islam, T., N. Afrin, S. Parvin, N. H. Dana, K. S. Rahman, W. Zzaman, and M. N. Islam (2018) The impact of chitosan and guava leaf extract as preservative to extend the shelf-life of fruits. International Food Research Journal 25, 2056-2062.

[22] Shalini, M. and D. P. Ritu (2018) Preparation of antioxidant rich healthy beverages by using pineapple juice and guava leaves extract flavoured with herbs (mint). International Journal of Advances in Scientific Research and Engineering 8, 46-52.

[23] Tabassum, P., S. A. K. U. Khan, M. Siddiqua, and S. Sultana (2018) Effect of guava leaf and lemon extracts on postharvest quality and shelf life of banana cv. Sabri (Musa sapientum L.). Journal of the Bangladdesh Agricultural University 16, 337342 .

[24] AOAC (2010) Official methods of analysis. 18th ed. Association of Official Analytical Chemists, Washington DC, USA.

[25] Meydav, S., I. Saguy, and I. J. Kopelman (1977) Browning determination in citrus products. Journal of Agricultural and Food Chemistry 25, 602-604.

[26] Osorio-Esquivel, O., V. B. Álvarez, L. Dorantes-Álvarez, and M. M. Giusti (2011) Phenolics, betacyanins and antioxidant activity in Opuntia joconostle fruits. Food Research International 44, 2160-2168.

[27] Ravichandran, K., N. M. M. T. Saw, A. A. Mohdaly, A. M. Gabr, A. Kastell, H. Riedel, Z. Cai, D. Knorr, and I. Smetanska (2013) Impact of processing of red beet on betalain content and antioxidant activity. Food Research International $50,670-675$. 
[28] Min, S., T. Jin, H. W. Yeom, S. K. Min, and Q. H. Zhang (2003) Commercial scale pulsed electric field processing of orange juice. Journal of Food Science 68, 1265-1271.

[29] Mall, P. and D. K. Tondon (2007) Development of guava aonla blended beverage. Acta Horticulture 735, 555-560.

[30] Bhardwaj, R. L. and S. Mukherjee (2011) Effects of fruit juice blending ratios on kinnow juice preservation at ambient storage condtion. African Journal of Food Science 5, 281-286.

[31] Rani, S., A. Zeb, M. Ayub, and U. Shahni (2018) Quality evaluation of mandarin and strawberry mixed fruit juice for total period of 90 days at room temperature. Pure and Applied Biology 7, 174-183.

[32] Saleh, E. A., A. E. M. Morshdy, A. E. Hafez, M. A. Hussein, E. S. Elewa, and A. F. A. Mahmoud (2017) Effect of pomegranate peel powder on the hygienic quality of beef sausage. Journal of Microbiology, Biotechnology and Food Sciences 6, 1300-1304.

[33] Kumar, K., A. Sharma, and A. Barmanray (2008) Storage stability of musambi (Citrus sinensis) RTS beverage in different storage conditions. Beverage and Food World 35, $47-48$.

[34] Mehmood, Z., A. Zeb, M. Ayub, N. Bibi, A. Badshah, and I. Ihsanullah (2008) Effect of pasteurization and chemical preservatives on the quality and shelf stability of apple juice. American Journal of Food Technology 3, 147-153.

[35] Embaby, H. E. S. and S. M. Mokhtar (2019) Impact of adding goldenberry (Physalis peruviana L.) on some quality characteristics and bio-functional properties of pasteurized carrot (Daucus carota L.) nectar. Journal of Food Science and Technology 56, 966-975.

[36] Chia, S. L., S. Rosnah, M. A. Noranizan, and W. D. Wan Ramli (2012) The effect of storage on the quality attributes of ultraviolet-irradiated and thermally pasteurized pineapple juices. International Food Research Journal 19, 1001-1010.
[37] Chen, H. Y. and G. C. Yen (2007) Antioxidant activity and free radical-scavenging capacity of extracts from guava (Psidium guajava L.) leaves. Food Chemistry 101, 686-694.

[38] Yasoubi, P., M. Barzegar, M. A. Sahari, and M. H. Azizi (2007) Total phenolic contents and antioxidant activity of pomegranate (Punica granatum L.) peel extracts. Journal of Agricultural Science and Technology 9, 34-42.

[39] Muzaffar, K., G. A. Nayik, A. Gull, and P. Kumar (2017) Changes in quality characteristics of pomegranate juice concentrate during refrigerated storage. Journal of Postharvest Technology 5, 16-21.

[40] Oziyci, H. R., M. Karhan, N. Tetik, and I. Turhan (2013) Effects of processing method and storage temperature on clear pomegranate juice turbidity and color. Journal of Food Processing and Preservation 37, 899-906.

[41] Adeogun, O. O., A. A. Adekunle, and E. M. Adongbede (2017) Effects of leaf extracts of selected plants on quality of stored Citrus sinensis (sweet orange) juice. Notulae Scientia Biologicae 9, 256-262.

[42] Vegara, S., N. Martí, P. Mena, D. Saura, and M. Valero (2013) Effect of pasteurization process and storage on color and shelf-life of pomegranate juices. LWT- Food Science and Technology 54, 592-596.

[43] P. I. Akubor (2017) Quality characteristics and storage properties of squash prepared from pineapple (Ananas comosus) fruit juice. Asian Journal of Biotechnology and Bioresource Technology 1, 1-8.

[44] Siow, L. F. and Y. M. Wong (2017) Effect of juice concentration on storage stability, betacyanin degradation kinetics, and sensory acceptance of red-fleshed dragon fruit (Hylocereus polyrhizus) juice. International Journal of Food Properties 20, 623-632. 